Developmental \& Comparative Immunology 2006; 30(4) : 367-379

http://dx.doi.org/10.1016/j.dci.2005.05.003

(c) 2005 Elsevier Ltd All rights reserved
Archimer, archive institutionnelle de l'Ifremer http://www.ifremer.fr/docelec/

\title{
Effects of extracellular products from the pathogenic Vibrio aestuarianus strain $01 / 32$ on lethality and cellular immune responses of the oyster Crassostrea gigas
}

\author{
Yannick Labreuche ${ }^{\mathrm{a}}$, Philippe Soudant $\mathrm{t}^{\mathrm{b}^{\mathrm{t}}}$, Madeleine Gonçalves ${ }^{\mathrm{b}}$, \\ Christophe Lambert ${ }^{b}$ and Jean-Louis Nicolas ${ }^{a}$
}

\begin{abstract}
aUnité Mixte de Recherche Physiologie et Ecophysiologie des Mollusques Marins, IFREMER, Centre de Brest, B.P. 70, 29280 Plouzané, France

bLaboratoire des Sciences de l'Environnement Marin, Institut Universitaire Européen de la Mer, Université de Bretagne Occidentale, Place Copernic, Technopôle Brest-Iroise. 29280 Plouzané, France

*: Corresponding author : Tel.: +33 2984986 23; fax: +33 2984986 45. philippe.soudant@univ-brest.fr
\end{abstract}

\begin{abstract}
Vibrio aestuarianus strain $01 / 32$ was previously shown to be pathogenic to Crassostrea gigas juveniles. To investigate virulence mechanisms of this pathogen, we studied the toxicity to oysters of its extracellular products (ECPs). ECPs displayed lethality to animals, with a LD50 value of $3.3 \mu \mathrm{g} / \mathrm{g}$ body weight. To determine the oyster cellular immune responses induced by these ECPs, we further examined in vitro their effects on $\mathrm{C}$. gigas hemocytes, using flow cytometric-based hemocyte assays. Treatment of hemolymph with ECPs caused a significant inhibition of hemocyte phagocytosis and adhesive capabilities. In contrast, the pathway of reactive oxygen species production was enhanced by higher ECP concentrations. Exposure of hemocytes to live bacteria induced no changes in hemocyte parameters. Together, these results suggest that $V$. aestuarianus strain $01 / 32$ secretes one or more factors which may play an important role in the pathogenicity of this microorganism, and which display immunosuppressant activities on hemocyte functions.
\end{abstract}

Keywords: Bivalve immunity; Flow-cytometry; Phagocytosis; Adhesion; ROS production; Crassostrea gigas; ECPs; Vibrio aestuarianus 


\section{Introduction}

Under intensive culture conditions, marine species are exposed to various stressors, including bacterial pathogens. Among possible sources of bacterial infections, Vibrio spp. are often associated with diseases in larval and adult stages of bivalves [1-5]. In France, since 1991, high mortality rates of Crassostrea gigas spat (60 to 100\%) have been reported during summer, both in the field and in hatcheries, and are of major concern to oyster farmers [6]. Several hypotheses concerning the etiology of these summer mortalities have been explored, including the involvement of potentiallypathogenic agents. To date, a herpes-like virus [7, 8] and several Vibrio splendidus strains [9-11] have been detected in oyster spat populations experiencing summer mortalities. Although these infectious agents were demonstrated to be pathogenic to $C$. gigas spat under experimental conditions, none could be systematically associated with the onset of these epizootics in the field [11]. One can hypothesize, therefore, that mortality could be the result of complex interactions between the physiological and/or genetic status of the host, numerous environmental factors, and one or more infectious agents acting more as opportunists than pathogens $[6,11]$.

To explore this hypothesis of opportunistic infection of stressed oysters, a bacterial strain was isolated from moribund C. gigas juveniles, sampled during a summer mortality outbreak in an experimental hatchery. Hemolymph of moribund animals contained a consistently-high load of bacteria, revealing septicemia, and was infected predominantly with a $V$. aestuarianus strain isolated and given the strain designation $01 / 32$. Its pathogenicity was assessed by experimental challenge, resulting in high $C$. gigas mortality rates (60-90\%) (M. Garnier, pers. comm.). Accordingly, this Vibrio strain was judged to be a suitable candidate for the study of bacterium-host interactions with C. gigas.

Although some manifestations of bacterial infections in oysters have been described (see references [12, 13] for a review), little is known about bacteria-induced host tissue alterations, as well as immune responses, compared to the studies on the pathogenic processes for vertebrates and plant pathogens. During the process of infection, bacteria are confronted by oyster cellular immune defenses, specifically by immuno-competent cells referred to collectively as hemocytes. These cells, which circulate within the oyster open vascular system and across all epithelial boundaries, constitute the main line of host internal defenses against parasites and pathogens. Some disagreements remain concerning the number of hemocyte sub-populations in bivalves, but attempts at developing a uniform classification of bivalve hemocytes have resulted in recognition of three major cell types: granulocytes, hyalinocytes and agranulocytes [14-16]. There is general agreement that granulocytes function most actively in the phagocytosis of bacteria. This activity is usually accompanied by the production of reactive oxygen species (ROS), also known as "respiratory burst", 
which display strong microbicidal activities. Hyalinocytes are less phagocytic than granulocytes and their main defense function appears to be wound repair (see references $[16,17]$ for a review). However, despite numerous histological and ultrastructural observations, the precise roles of these basic cell types, the mechanisms by which they function, and their susceptibility to bacteria remain poorly understood.

Previous studies demonstrated that bacteria possess different survival capabilities in bivalve tissues and hemolymph $[18,19]$. This difference in susceptibility may depend on several factors, which may include avoiding contact with phagocytic hemocytes, inhibition of phagocytic engulfment, survival inside phagocytic cells, and the production of components that kill or damage hemocytes [20]. For example, $V$. tapetis, the causative agent of brown ring disease (BRD) in the clam Ruditapes philippinarum, avoids phagocytic engulfment by impairing hemocyte adhesion properties [21]. Some bacteria possess the capacity to inhibit the ROS production associated with phagocytosis. Bramble et al. [22] demonstrated, using chemiluminescence (CL) assays, that the bacterium Listonella anguillarum expresses an antioxidant enzyme, suppressing the production of ROS by C. virginica hemocytes. In addition, Vibrio sp. strain S322 was shown by flow-cytometric measurements to inhibit the CL response of scallop and oyster hemocytes [23, 24] and the ROS production of C. gigas hemocytes [25]. An understanding of interactions between pathogenic bacteria and oyster hemocytes is, therefore, of particular interest to elucidate mechanisms responsible for bacterial persistence in oyster fluids and tissues.

In the past, the virulence of pathogenic Vibrio spp. isolated from oysters was shown to be related to their ability to produce extracellular products (ECPs) [1,2]. According to Maeda et al. [26], these ECPs, mostly consisting of proteases, could facilitate the propagation of the bacteria by causing extensive host tissue damage, thereby degrading host proteins to provide readily-available nutriments for bacterial growth. Furthermore, ECPs could also counteract the host defense system by degrading immunoglobulins and components of the complement system, for example [26]. Mechanisms involved in the pathogenicity of $V$. aestuarianus $01 / 32$ to oysters are currently unknown, and the contribution of extracellular products to the pathogenesis of this strain needs to be ascertained. This study was aimed at investigating the overall hypothesis that V. aestuarianus 01/32 ECPs impair immunity and survival of oysters. Specifically, the present work was designed to determine the toxicity of $V$. aestuarianus $01 / 32$ ECPs in vivo and to evaluate in vitro the oyster cellular-immune responses after exposure to these extracellular products. 


\section{Materials and methods}

\subsection{Oysters}

One-year-old oysters $C$. gigas (mean weight $5 \pm 1 \mathrm{~g}$ ) were provided by a French commercial hatchery (SATMAR, Lannilis, France) and grown out in Aber Benoît (Finistère, France). Animals were acclimated for two weeks in the laboratory (IFREMER, Plouzané, France) in a flow-through seawater system at ambient temperature $\left(13-15^{\circ} \mathrm{C}\right)$ and salinity (33-35\%), and were fed a mixture of two marine microalgae: Isochrysis aff. galbana clone T-Iso (also termed Tahitian Isochrysis) and Pavlova lutheri.

\subsection{Preparation of $V$. aestuarianus 01/32 bacterial suspension}

A Vibrio sp. was previously isolated from 18 month-old oysters (C. gigas) during a mortality outbreak occurring in June 2001 at the IFREMER experimental hatchery (Finistère, France). This Vibrio sp. was identified as V. aestuarianus by phenotypic (API 20E and $50 \mathrm{CH}$ identification kits, BioMérieux France) and genotypic methods, based on phylogenetic analyses of 16S ribosomal DNA (GenBank accession number AJ845023) and gyrase B subunit (GenBank accession number AJ582818) genes (M. Garnier, pers. comm.). The strain was given the designation 01/32. V. aestuarianus strain 01/32 was routinely cultured in Marine Broth (MB, Difco) $\left(20^{\circ} \mathrm{C}, 20-\mathrm{h}\right.$, shaker table at 200-rpm). Bacterial cells were harvested by centrifugation $(1,500 \mathrm{XG}, 10-\mathrm{min})$, washed twice with filtered $(0.22-\mu \mathrm{m})$ sterile seawater (FSSW) and resuspended in FSSW. Bacterial cell concentration was estimated using a cell number-optical density (550-nm) relationship previously established.

\subsection{Preparation of $V$. aestuarianus $01 / 32$ extracellular products}

Bacterial ECPs were produced by the cellophane overlay method as described by Liu et al. [27]. Tubes containing 5-mL of MB were inoculated with one bacterial colony from a 24-h Marine Agar (MA, Difco) culture of V. aestuarianus strain $01 / 32$ and incubated at $20^{\circ} \mathrm{C}$ for $18-\mathrm{h}$. A volume of $2-\mathrm{mL}$ of this culture was transferred onto a sterile cellophane film placed on the surface of each MA plate. After incubation at $20^{\circ} \mathrm{C}$ for 48 -h, the cellophane overlay was transferred to an empty Petri dish. Cells were washed off the cellophane film using 4-mL of cold FSSW and removed by centrifugation at $10,000 \mathrm{XG}$ and $4^{\circ} \mathrm{C}$ for 30 -min. The supernatant containing the ECPs was sterilized by filtration $(0.22-$ $\mu \mathrm{m})$ and stored at $-80^{\circ} \mathrm{C}$ until use. The protein concentration of the ECPs was measured by the method of Bradford 
[28], with bovine serum albumin (Sigma) as the standard.

\subsection{ECP toxicity testing and $L D_{50}$ determination}

The role of ECPs in the pathogenicity of $V$. aestuarianus $01 / 32$ to $C$. gigas was evaluated, and the $50 \%$ lethal dose $\left(\mathrm{LD}_{50}\right)$ was determined. To anaesthetize oysters and open the valves, animals were first kept for 3-h in a $\mathrm{MgCl}_{2}$ bath at a final concentration of $50-\mathrm{g} . \mathrm{L}^{-1}(2 / 3 \mathrm{v} / \mathrm{v}$ seawater/freshwater), according to the method of Gay et al. [29]. A volume of $0.2 \mathrm{~mL}$ of the ECP solution was then injected into the adductor muscle of each oyster. Four different doses of ECPs $(1.25,2.5,5$ and $10 \mu \mathrm{g}$ protein/g body weight) were tested, and each dose was injected into 10 oysters. As controls, one group of 10 oysters was injected with FSSW, and an additional group was not injected. Immediately after injection, oysters were transferred to aquariums containing aerated filtered seawater at ambient temperature $\left(19 \pm 1^{\circ} \mathrm{C}\right)$ and kept under static conditions. Observations were made twice a day, and mortalities were recorded for 7-days after injection. Animals were considered as dead when the valves did not shut anymore and the mantle did not react after stimulation by prick. The experiment was carried out in duplicate and $\mathrm{LD}_{50}$ values were calculated by the statistical method of Reed \& Müench [30].

\subsection{Hemolymph sampling and hemocyte parameters}

A small notch was carved in the dorsal side of the shell, adjacent to the adductor muscle, of unchallenged oysters. Hemolymph samples were withdrawn from the adductor muscle using a 1-mL plastic syringe fitted with a 25 -gauge needle, and samples were stored individually in micro-tubes held on ice, to minimize cell clumping. Individual samples were observed under the optical microscope to control the quality of the hemolymph used subsequently and to prevent gut-bacterial or gamete contamination. Hemolymph was then filtered through $80-\mu \mathrm{m}$ mesh, and five individual samples were pooled. Four pools were prepared for each treatment. This operation was repeated for each of the experiments performed.

\section{Phagocytosis of fluorescent beads}

The phagocytosis assay was adapted from the method of Delaporte et al. [31], using fluorescent, latex beads (Fluoresbrite, YG Microspheres, $2 \mu \mathrm{m}$, Polysciences). 300- $\mu \mathrm{L}$ sub-samples of each hemolymph pool were distributed into 5 -mL polystyrene tubes $\left(\right.$ Falcon $\left.{ }^{\circledR}\right)$ and maintained on ice. ECPs or bacteria $(300-\mu \mathrm{L})$ were added according to 
experimental design described below. A control was included by adding FSSW $(300-\mu \mathrm{L})$ to one sub-sample of each pool. Each sub-sample was subsequently incubated with $30-\mu \mathrm{L}$ of fluorescent bead working solution $(2 \%$ of the commercial solution in FSSW) at $18^{\circ} \mathrm{C}$ for 60 -min. Tubes were then analyzed on the flow cytometer. As the number of beads engulfed in hemocytes differed, several fluorescence peaks were visible on the cytogram, corresponding to the number of beads associated with the hemocytes (Fig. 1). Results of phagocytosis were expressed as the percentage of hemocytes containing three beads or more, according to Delaporte et al. [31] and Hégaret et al. [32].

\section{Adhesive capacity}

To estimate hemocyte adhesion capacity, $100-\mu \mathrm{L}$ sub-samples of each hemolymph pool were distributed into 24 -well microplates maintained on ice. Each sub-sample received a 100- $\mu$ l volume of ECPs or bacteria, or $100-\mu \mathrm{L}$ of FSSW as a control. After three hours of incubation at $18^{\circ} \mathrm{C}$, cells were fixed by addition of $200-\mu \mathrm{L}$ of a $6 \%$ formalin solution in FSSW. Concentration of non-adherent cells was established according to the method described by Delaporte et al. [31]. For each condition, the percentage of adhering hemocytes was calculated relatively to the initial total hemocyte count of the tested pool.

\section{Reactive oxygen species (ROS) production}

The method using 2'7'-dichlorofluorescin diacetate (DCFH-DA, Sigma), previously described in mammals by Bass et al. [33], was adapted to C. gigas by Lambert et al. [25] and to C. virginica by Hégaret et al. [34] was used. Briefly, intracellular DCFH oxidation is quantitatively related to the oxidative metabolism of hemocytes and primarily mediated by $\mathrm{H}_{2} \mathrm{O}_{2}$ but also by other ROSs, such as superoxide anion, peroxyl radical and peroxynitrite anion [35]. DCF production results in green fluorescence, which is measured on the FL1 detector of the flow cytometer.

A $150-\mu \mathrm{L}$ sub-sample of hemolymph from each pool was distributed into a 5-mL polystyrene tube (Falcon $\left.{ }^{\circledR}\right)$, diluted $(+450-\mu \mathrm{L})$ with FSSW and maintained on ice. Each sub-sample received a 300- $\mu$ l volume of ECPs or bacteria, or $300-$ $\mu \mathrm{L}$ of FSSW as a control. DCFH-DA working solution was finally added in each tube maintained on ice to yield a final concentration of $10-\mu \mathrm{M}$. Tubes were then incubated for 60 and 120 -min at room temperature in the dark. The DCF green fluorescence level was evaluated for the three hemocyte sub-populations: agranulocytes, hyalinocytes and granulocytes, distinguished according to their relative size (forward scatter, FSC) and complexity (side scatter, SSC) (Fig. 2). Small agranulocytes showing very low ROS production; values for hyalinocytes and granulocytes only are presented here. Results are given for both hemocyte sub-populations as mean of fluorescence in FL1 arbitrary units. 


\subsection{Hemocyte responses to different concentrations of ECPS}

A first set of experiments was conducted in vitro to determine the effect of increasing concentrations of bacterial ECPs on several hemocyte parameters. ECPs $(300-\mu \mathrm{L})$ were added to obtain final concentrations of 2, 4, 8, 16, 32, 64 and $128-\mu \mathrm{g} \cdot \mathrm{mL}^{-1}$. Measurements of phagocytosis, adhesion, and ROS production by hemocytes were processed as described above.

\subsection{Minimal inhibitory concentration of ECPS}

A second set of experiments was performed to determine the minimal inhibitory concentration of ECPs on hemocyte phagocytic and adhesive activities. Hemolymph sub-samples were treated following the methods described above, except that ECPs were added at lower concentrations than previously tested, ranging from 0.1 to $2-\mu \mathrm{g} \cdot \mathrm{mL}^{-1}(0.1,0.5,1$ and $\left.2-\mu \mathrm{g} \cdot \mathrm{mL}^{-1}\right)$.

\subsection{Comparison of V. aestuarianus 01/32 live cells and ECPs on hemocyte responses}

A third set of experiments was performed to evaluate the influence of live bacterial cells on phagocytic, adhesive and ROS-producing capacities of hemocytes, in comparison to low $\left(2-\mu \mathrm{g} \cdot \mathrm{mL}^{-1}\right)$ and intermediate $\left(32-\mu \mathrm{g} \cdot \mathrm{mL}^{-1}\right)$ doses of ECPs. To adjust the bacteria/hemocyte ratio, the hemocyte concentration of pooled hemolymph was evaluated according to Lambert et al. [25]. The $V$. aestuarianus $01 / 32$ bacterial suspension was prepared so as to obtain a ratio of 50 bacteria per hemocyte (final concentration). Thereafter, the same experimental procedures as described above were used. Incubation time and measurement remained the same as those previously established.

\subsection{Statistical analysis}

Significant differences between treatments during each assay were tested by one-way analysis of variance (ANOVA), or Kruskal-Wallis test in case of heterogeneity of variances, using Statgraphics Plus 4.1 software. Data collected as percentages were transformed (arcsine of the square root) before analysis but are presented in figures as untransformed percentage values. The method used to discriminate among the means was Fisher's least significant difference (LSD) procedure. Results were deemed significant at $\mathrm{P}<0.05$. 


\section{Results}

\subsection{ECP toxicity testing and $L D_{50}$ determination}

The $\mathrm{LD}_{50}$ value was 3.3- $\mu \mathrm{g}$ protein. $\mathrm{g}^{-1}$ body weight (Table 1). Oysters injected with ECPs died rapidly, all recorded deaths occurring within 24-h post inoculation. No mortality was observed in the FSSW or uninjected control groups.

\subsection{Hemocyte responses to different concentrations of ECPS}

Phagocytic activity: After 1-h incubation, phagocytic activity was significantly affected by a concentration of ECPs as low as $2-\mu \mathrm{g} \cdot \mathrm{mL}^{-1}$, resulting in a $30 \%$ loss of hemocyte phagocytic activity (ANOVA, $\left.\mathrm{P}<0.05\right)($ Fig. 3 ). Inhibition of phagocytosis by ECPs was dose-dependent and reached a maximum at a concentration of $16-\mu \mathrm{g} \cdot \mathrm{mL}^{-1}(\mathrm{ANOVA}, \mathrm{P}<$ 0.05), with a decrease of $64.9 \%$ of the phagocytic ability, compared to the FSSW control. Concentrations of ECPs above $16-\mu \mathrm{g} \cdot \mathrm{mL}^{-1}$ did not significantly result in an additional inhibition of phagocytic activity.

Adhesive capacity: After 3-h of incubation, hemocyte capacity for adhesion was significantly inhibited by ECPs at the lowest concentration $\left(2-\mu \mathrm{g} \cdot \mathrm{mL}^{-1}\right)$, with a decrease of $21 \%$ compared to the control (Kruskal-Wallis test, $\mathrm{P}<0.05$ ) (Fig. 4). This inhibition was observed to be similar for all the tested concentrations and was thus not dose-dependent.

ROS production: The synthesis of ROS increased with incubation time in control sub-samples for the two hemocyte sub-populations (i.e. granulocytes and hyalinocytes), this activity being higher in granulocytes compared to hyalinocytes after 60 and 120-min of incubation (Fig. 5). The ROS production of granulocytes significantly increased from a concentration of $64-\mu \mathrm{g} \cdot \mathrm{mL}^{-1}$ of ECPs after 60 and 120-min of incubation, representing, respectively, an increase of $52.8 \%$ and $20.5 \%$ compared to the FSSW control (ANOVA, $\mathrm{P}<0.05$ ). Hyalinocytes were more sensitive than granulocytes, as the ROS production of hyalinocytes was significantly enhanced by $16-\mu \mathrm{g} . \mathrm{mL}^{-1}$ of ECPs $(+25.5 \%$ compared to the control). After 120-min of incubation, a higher concentration of ECPs was necessary to obtain a significant increase in hyalinocyte ROS production. Indeed, DCF fluorescence significantly differed from the control at the same concentration of ECPs as that observed for granulocytes (i.e. $64-\mu \mathrm{g} \cdot \mathrm{mL}^{-1}$ ), with an increase of $30.5 \%$ (ANOVA, $\mathrm{P}<0.05$ ). 


\subsection{Minimal inhibitory concentration of ECPS}

Phagocytic activity: as indicated in Fig. 6, this activity was significantly affected from a concentration of ECPs as low as $0.5-\mu \mathrm{g} \cdot \mathrm{mL}^{-1}$, with hemocytes retaining only $55.3 \%$ of their original phagocytic activity (ANOVA, P $<0.05$ ). As previously observed, this inhibition appeared to be dose-dependent with a concentration of ECPs of $2-\mu \mathrm{g} \cdot \mathrm{mL}^{-1}$ leading to a decrease of $75.8 \%$ of the phagocytic ability, compared to control hemocytes.

Adhesive capacity: as shown in Fig. 7, addition of ECPs to hemolymph induced a dose-dependent inhibition of hemocyte adhesive capacity over the range of 0.5 to $2-\mu \mathrm{g} \cdot \mathrm{mL}^{-1}$, the minimal inhibitory concentration of ECPs being 0.5 $\mu \mathrm{g} . \mathrm{mL}^{-1}$ with a decrease of adhesive capacity of $5.1 \%$ compared to the control (ANOVA, $\mathrm{P}<0.05$ ).

\subsection{Comparison of $V$. aestuarianus 01/32 live cells and ECPs on hemocyte responses}

Phagocytic activity: confirming the results previously obtained, $V$. aestuarianus extracellular products significantly inhibited the phagocytic activity of $C$. gigas hemocytes in a dose-dependent manner (Fig. 8). For the same incubation time, live $V$. aestuarianus $01 / 32$ cells at 50 bacteria per hemocyte did not induce any significant difference in phagocytic capability (Kruskal-Wallis test, $\mathrm{P}<0.05)$.

Adhesive capacity: As in the previous experiment, ECPs inhibited hemocyte adhesion properties with doses of 2 and $32-$ $\mu$ g.mL $\mathrm{m}^{-1}$ after 3-h of incubation (Fig. 9). After exposure to live $V$. aestuarianus 01/32 cells, the percentage of adherent hemocytes did not significantly differ from that of the control (ANOVA, $\mathrm{P}<0.05$ ).

ROS production: As presented in Fig. 10, addition of ECPs at 32- $\mu \mathrm{g} . \mathrm{mL}^{-1}$ led to a significant increase in granulocyte and hyalinocyte ROS production $(+53.5 \%$ and $+50.4 \%$ after 60 -min of incubation, $+57.4 \%$ and $+55.4 \%$ after 120 -min of incubation, respectively) compared to the FSSW control. At 2- $\mu \mathrm{g} \cdot \mathrm{mL}^{-1}$ of ECPs, ROS production of granulocytes and hyalinocytes increased slightly, but not significantly. Conversely, stimulation or inhibition of hemocyte ROS production did not occur, in either sub-population, in response to $V$. aestuarianus $01 / 32$ live cells, regardless of incubation time (ANOVA, $\mathrm{P}<0.05$ ). 


\section{Discussion}

\subsection{ECPs display lethality to C. gigas oysters}

$V$. aestuarianus $01 / 32 \mathrm{ECP}$ activities were evaluated in vivo by injection into the adductor muscle of $C$. gigas oysters. In this experimental system, the toxicity of $V$. aestuarianus $01 / 32$ ECPs was clearly demonstrated. The calculated $\mathrm{LD}_{50}$ value (3.3- $\mu \mathrm{g}$ protein per $\mathrm{g}$ of body weight) was comparable to those reported for other marine mollusk pathogens of the Vibrio genus [36]. However, ECPs of $V$. aestuarianus 01/32 displayed a particularly strong toxic effect, as all recorded mortalities occurred within $24-\mathrm{h}$ post inoculation. In comparison, the susceptibility of the small abalone Haliotis diversicolor supertexta to $V$. parahaemolyticus ECPs was weaker, since moribund animals were observed up to 7 days post challenge [37]. $V$. aestuarianus strain $01 / 32$ secretes a highly-toxic material that could play an important role in virulence mechanisms.

\subsection{ECPs inhibit hemocyte phagocytosis and adhesive capacities}

Bivalve hemocytes spontaneously develop cytoplasmic extensions (pseudopods) and rapidly adhere when they are placed on flat surfaces. These abilities of hemocytes have been demonstrated to be affected by live cells of some Vibrio spp. known to be pathogenic to bivalves. For example, V. alginolyticus and $V$. anguillarum cells induced loss of pseudopods and cell rounding of Mytilus edulis hemocytes [38, 39]. Similarly, Choquet et al. [21] demonstrated, using a flow cytometry-based technique, that 3-h incubation of clam $R$. philippinarum hemocytes with $V$. tapetis live cells led to a marked reduction in hemocyte adhesive capabilities. This technique was adapted here to quantify the effects of $V$. aestuarianus 01/32 ECPs on the adhesive capabilities of oyster, C. gigas, hemocytes. Indeed, microscopic observations showed that ECPs produced by this Vibrio strain affected oyster hemocytes by causing cell rounding and lost of pseudopods (data not shown). The flow-cytometric assay, based on the counting of non-adherent hemocytes, allowed demonstration that a concentration of ECPs as low as $0.5-\mu \mathrm{g} \cdot \mathrm{mL}^{-1}$ resulted in a significant decrease in hemocyte adhesive capabilities. Previous assays with other Vibrio extracellular products have been performed in fish or human cell lines. For instance, $V$. cholerae Non-O1 was shown to produce a non-membrane damaging cytotoxin (NMDCY), also known as cell rounding factor, which caused rapid rounding of HeLa cultured cells [40]. ECPs of $V$. tapetis induced vacuolization of fish cells and several morphological alterations [41]. In bivalve mollusks, such observations of hemocyte alterations caused by Vibrio strains or their ECPs are scarce. To the best of our knowledge, this is the first report of a cytotoxic effect of ECPs on the adhesive capabilities of bivalve hemocytes. 
To further examine effects of ECPs on C. gigas hemocytes, we investigated the ability of hemocytes treated in vitro with ECPs to engulf fluorescent latex beads by phagocytosis. Data obtained correlated well with adhesion results. After 1-h of exposure to ECPs, phagocytosis was significantly affected by a concentration of $0.5-\mu g . \mathrm{mL}^{-1}$, hemocytes maintaining only $55.3 \%$ of their original phagocytic activity. Furthermore, this inhibitory effect appeared to be dosedependent for tested concentrations of ECPs. The process of engulfing foreign particles (i.e. phagocytosis) is driven by a finely-controlled rearrangement of the actin cytoskeleton, involving pseudopod formation, which is an essential part of this phagocytic activity [42]. Taken together, all results suggest a close relationship between the loss of cytoplasmic extensions, the reduction of adhesion properties, and the inhibition of phagocytosis attributable to ECPs. The results also indicate that $V$. aestuarianus strain $01 / 32$ secretes one or more phagocytosis- and adhesion-inhibiting factors. Few examples of pathogenic Vibrio producing substances biologically active against marine bivalve hemocytes are known [38]. Furthermore, none of these bacterial substances were shown to possess anti-phagocytic activity. Such an interaction was only demonstrated in the lepidopteran model host Manduca sexta, for which previous research showed that the supernatant of the insect pathogenic bacterium Photorhabdus strain W14 was able to suppress the phagocytosis of bacteria by Manduca hemocytes [43, 44].

\subsection{ECPs affect ROS production in C. gigas hemocytes}

C. gigas hemocyte ROS production was activated in a dose-dependent manner, significantly from a concentration of ECPs of $64-\mu \mathrm{g} \cdot \mathrm{mL}^{-1}$ for granulocytes whatever the incubation time, and for hyalinocytes from $16 \mu \mathrm{g} \cdot \mathrm{mL}^{-1}$ and $64-$ $\mu \mathrm{g} . \mathrm{mL}^{-1}$ after 60 and 120-min, respectively. These results are consistent with those previously obtained by Lambert $e t$ al. [45] showing that ECPs of $V$. aestuarianus strain 01/32 led to a significant stimulation of hemocyte ROS production. The observed increase in ROS production in both studies was higher than observed by Lambert et al. [25] after zymosan activation using the same measurement technique. These authors also proposed that ROS production is triggered after bleeding and hemolymph handling without use of conventional stimulants (phorbol-12-myristate 13acetate (PMA) or zymosan). The ROS production by C. gigas hemocytes maintained in seawater after bleeding corresponds to our control treatment, but was not affected by ECPs at the range of concentrations affecting phagocytosis and adhesion.

The generation of cytotoxic ROS is a general protective mechanism in most, if not all, animal species. The production of these ROS compounds has been associated with phagocytosis in vertebrates as well as in bivalves [16, 46, 47]. As a consequence, an inhibition of hemocyte phagocytic processes could reasonably be expected to result in a subsequent 
decrease in ROS production. Our data are, consequently, surprising and could appear contradictory, with clear inhibition of hemocyte adhesion and phagocytosis by ECPs. In many cases, bacteria evade hemocyte killing by preventing ROS production. For instance, different strains of Vibrio, known or suspected to be pathogenic to bivalves, were shown to inhibit the ROS production capacity of zymosan-stimulated hemocytes [25]. Considering the role of ECPs, Densmore et al. [48] demonstrated a dose-dependent relationship between the concentration of R. salmoninarum ECPs and the inhibition of ROS production by trout phagocytes, previously stimulated by addition of PMA. In vitro treatment of Scophthalmus maximus (L.) macrophages with $V$. pelagius ECPs caused a significant inhibition in the chemiluminescence (CL) response of PMA-activated phagocytes [49]. Therefore, the results obtained with ECPs from the bacterial strain 01/32 appear to suggest a different mechanism. Indeed, few studies report data on the ability of ECPs to exert cellular responses through the generation of ROS. Hofman et al. [50] and Falzano et al. [51] provided evidence that the cytotoxic necrotizing factor $1(\mathrm{CNF}-1)$, a protein toxin produced by pathogenic strains of $E$. coli, stimulated ROS production in human polymorphonuclear leukocytes (PMNL). This effect was shown to be associated with a decrease in PMNL phagocytic function $[50,51]$. According to these authors, this excessive generation of ROS may enhance the virulence of $E$. coli infections by provoking damage to host epithelial cells [50].

Overall, data obtained here may support a model wherein ECPs impair hemocyte adhesive and phagocytic activities. Over-activation of ROS production may promote cytotoxicity in host hemocytes, allowing V. aestuarianus $01 / 32$ cells to overcome cellular defenses of $C$. gigas, thereby facilitating bacterial growth and dissemination in host tissues. This excessive production of ROS, possibly toxic for host cells, should display the same toxicity for bacterial cells. However, most of bacteria possess antioxidants in the form of enzymes (e.g., superoxide dismutases, peroxydases). To counteract elevated levels of $\mathrm{H}_{2} \mathrm{O}_{2}$, it has been shown that many aerobic bacteria produce catalase, a high-molecular-weight protein whose primary function is to destroy $\mathrm{H}_{2} \mathrm{O}_{2}$, leaving $\mathrm{H}_{2} \mathrm{O}$ and $\mathrm{O}_{2}$ as by-products [52]. Pseudomonas aeruginosa was shown to possess high catalase activity, involved in resistance to increasing concentrations of $\mathrm{H}_{2} \mathrm{O}_{2}$ [52]. Bramble et al. [22] hypothesized that L. anguillarum catalase could suppressed the CL generated by C. virginica hemocytes. In a similar manner, one could assume that $V$. aestuarianus strain $01 / 32$ possesses the ability to degrade the host-generated ROS by producing antioxidant enzymes. The production of such enzymes by the bacterium will be further investigated.

\subsection{Viable V. aestuarianus $01 / 32$ cells do not alter in vitro oyster immune parameters}

As shown in the Results section, live bacteria demonstrated activity on neither hemocyte adhesive capacity and 
phagocytosis, nor on ROS production when tested at a ratio of 50 bacteria per hemocyte and within a limited incubation time. According to this result, it could be hypothesized that the phagocytosis- and adhesion-inhibiting factor(s) could be mainly produced when the bacteria enter the exponential growth phase, i.e., are actively growing. This assumption is supported by the fact that bacterial cells were washed with FSSW before their addition to hemocytes, to eliminate all products secreted into the medium. Bacteria were subsequently exposed to hemocytes only for a short period of time (1$\mathrm{h}$ for phagocytosis and ROS production assays, 3-h for adhesion assays). Moreover, ECPs used in this study were obtained by harvesting a 2 day-old culture, when bacteria reach the stationary phase of growth. As a consequence, it could be that the time of pre-incubation of bacteria with hemocytes may have been insufficient to allow the production and the release of these factors by live cells. Preliminary in vivo experiments (data not shown) have shown dramatic decreases in hemocyte adhesive and phagocytic properties of $V$. aestuarianus $01 / 32$ infected oysters, compared to animals injected with FSSW. These observed effects occurred relatively slowly, requiring approximately 72-h post challenge to be significant. These data corroborate in vitro results presented in this study, and correlate well with the normal infection process, since this strain provokes an outbreak of mortality in C. gigas oysters 3 or 4 days after exposure (unpublished data). Assessing oyster immune parameters in response to a bacterial infection with V. aestuarianus $01 / 32$ will be further investigated.

We describe in this work the toxicity to oysters of extracellular products from a pathogenic Vibrio strain and demonstrate the bacterium's capacity to reduce hemocyte adhesion properties and phagocytosis, and to increase the production of reactive oxygen species. These findings provide new insights into the cellular basis of bacteria-hemocyte interactions. This may help to explain how a bacterial pathogen succeeds in avoiding phagocytic engulfment to multiply to unsafe levels in oysters, ultimately leading to death.

\section{Acknowledgments}

The authors are indebted to Dr G. H. Wikfors, NOAA Fisheries, Northeast Fisheries Science Center (Connecticut, USA) for the critical review of the first draft of the manuscript and for his help in editing the English language. We also acknowledge M. Garnier (LPI, Ifremer Brest, France) for technical assistance, and Dr C. Paillard (LEMAR, Plouzané, France) for her helpful comments and for giving access to microscopy equipment. This work was supported by the MOREST national project funded by Ifremer and by the Régions Basse-Normandie, Bretagne, Pays de la Loire and 
Poitou-Charentes and the Conseil Général du Calvados. Y. L. was supported by a doctoral grant from Ifremer and Région Bretagne. Contribution N944 of the IUEM, European Institute for Marine Studies (Brest, France)

\section{References}

[1] Nottage, A.S. and Birkbeck, T.H. (1987) Purification of a proteinase produced by the bivalve pathogen Vibrio alginolyticus NCMB 1339. Journal of Fish Diseases 10, 211-220.

[2] Elston, R.A. and Leibovitz, L. (1980) Pathogenesis of experimental vibriosis in larval American oysters, Crassostrea virginica. Can. J. Fish Aquat. Sci. 37, 964-978.

[3] Jeffries, V.E. (1982) Three Vibrio strains pathogenic to larvae of Crassostrea gigas and Ostrea edulis. Aquaculture $29,201-226$.

[4] Sugumar, G., Nakai, T., Hirata, Y., Matsubara, D. and Muroga, K. (1998) Vibrio splendidus biovar II as the causative agent of bacillary necrosis of Japanese oyster Crassostrea gigas larvae. Diseases of Aquatic Organisms 33, 111-118.

[5] Nicolas, J.L., Basuyaux, O., Mazurie, J. and Thebault, A. (2002) Vibrio carchariae, a pathogen of the abalone Haliotis tuberculata. Diseases of Aquatic Organisms 50, 35-43.

[6] Goulletquer, P., Soletchnick, P., Le Moine, O., Razt, D., Geairon, P., Faury, N. and Taillade, S. (1998) Summer mortality of the Pacific cupped oyster Crassostrea gigas in the Bay of Marennes-Oléron (France). Ices Statutory Meeting, Population Biology, Mariculture Committee CM CC14-CC20.

[7] Renault, T., Cochennec, N., Le Deuff, R.M. and Chollet, B. (1994) Herpes-like virus infecting Japanese oyster (Crassostrea gigas) spat. Bull. Eur. Assoc. Fish Pathol. 14, 64-65.

[8] Renault, T., Le Deuff, R.M., Cochennec, N., Chollet, B. and Maffart, P. (1995) Herpes-like viruses associated with high mortality levels in larvae and spat of Pacific oysters, Crassostrea gigas: a comparative study, the thermal effects on virus detection in hatchery-reared larvae, reproduction of the disease in axenic larvae. Vet. Res. 26, 539-543.

[9] Lacoste, A., Jalabert, F., Malham, S., Cueff, A., Gelebart, F., Cordevant, C., Lange, M. and Poulet, S. (2001) A Vibrio splendidus strain is associated with summer mortality of juvenile oysters Crassostrea gigas in the Bay of Morlaix (North Brittany, France). Diseases of Aquatic Organisms 46, 139-145.

[10] Waechter, M., Le Roux, F., Nicolas, J.L., Marissal, E. and Berthe, F. (2002) Caractérisation de bactéries pathogènes de naissain d'huître creuse Crassostrea gigas. C. R. Biologies 325, 231-238. 
[11] Le Roux, F., Gay, M., Lambert, C., Waechter, M., Poubalanne, S., Chollet, B., Nicolas, J.L. and Berthe, F. (2002) Comparative analysis of Vibrio splendidus-related strains isolated during Crassostrea gigas mortality events. Aquatic Living Resources 15, 251-258.

[12] Paillard, C., Le Roux, F. and Borrego, J.J. (2004) Bacterial disease in marine bivalves, a review of recent studies : Trends and evolution. Aquatic Living Resources 17, 477-498.

[13] Elston, R.A. (1993) Infectious diseases of the Pacific oyster, Crassostrea gigas. Annual Review of Fish Diseases 259-276.

[14] Auffret, M. (1988) Bivalve hemocyte morphology. Am. Fish. Soc. Special Pub. 18, 169-177.

[15] Cheng, T.C. (1996) Hemocytes: Forms and functions. The Eastern Oyster Crassostrea virginica (V.S. Kennedy, R.I.E. Newell, \& A.F. Eble, eds.) Maryland Sea Grant, College Park, MD, USA. 299-333.

[16] Chu, F.-L.E. (2000) Defense mechanisms of marine bivalves. In Recent Advances in Marine Biotechnology. Immunobiology and Pathology, (ed. M. Fingerman and R. Nagabhushanam). Enfield, NH, Plymouth, UK: Science Publishers. 5, 1-42.

[17] Hine, P.M. (1999) The inter-relationships of bivalve haemocytes. Fish \& Shellfish Immunology 9, 367-385.

[18] Marino, A., Crisafi, G., Maugeri, T.L., Nostro, A. and Alonzo, V. (1999) Uptake and retention of Vibrio cholerae non-O1, Salmonella typhi, Escherichia coli and Vibrio harveyi by mussels in seawater. New Microbiol. 22, 129-138.

[19] Genthner, F.J., Volety, A.K., Oliver, L.M. and Fisher, W.S. (1999) Factors Influencing In Vitro Killing of Bacteria by Hemocytes of the Eastern Oyster (Crassostrea virginica). Applied and Environmental Microbiology 65, 3015-3020.

[20] Cheng, T.C. (1975) Functional morphology and biochemistry of molluscan phagocytes. Ann. NY Acad. Sci. 266, 343-379.

[21] Choquet, G., Soudant, P., Lambert, C., Nicolas, J.L. and Paillard, C. (2003) Reduction of adhesion properties of Ruditapes philippinarum hemocytes exposed to Vibrio tapetis. Diseases of Aquatic Organisms 57, 109-116.

[22] Bramble, L. and Anderson, R.S. (1997) Modulation of Crassostrea virginica hemocyte reactive oxygen species production by Listonella anguillarum. Developmental \& Comparative Immunology 21, 337-348.

[23] Lambert, C. and Nicolas, J.-L. (1998) Specific inhibition of chemiluminescent activity by pathogenic Vibrios in hemocytes of two marine bivalves : Pecten maximus and Crassostrea gigas. Journal of Invertebrate Pathology 71, 5363.

[24] Lambert, C., Nicolas, J.L. and Bultel, V. (2001) Toxicity to bivalve hemocytes of pathogenic Vibrio cytoplasmic extract. Journal of Invertebrate Pathology 77, 165-172. 
[25] Lambert, C., Soudant, P., Choquet, G. and Paillard, C. (2003) Measurement of Crassostrea gigas hemocyte oxidative metabolism by flow cytometry and the inhibiting capacity of pathogenic vibrios. Fish \& Shellfish Immunology 15, 225-240.

[26] Maeda, H. and Yamamoto, T. (1996) Pathogenic mechanisms induced by microbial proteases in microbial infections. Biol. Chem. Hoppe Seyler 377, 217-226.

[27] Liu, P.V. (1957) Survey of hemolysin production among species of Aeromonas hydrophila with reduced virulence for fish. Infection and Immunity 74, 718-727.

[28] Bradford, M.M. (1976) A rapid and sensitive method for the quantitation of microgram quantities of protein utilizing the principle of protein-dye binding. Analytical Biochemistry 72, 248-254.

[29] Gay, M., Berthe, F.C.J. and Le Roux, F. (2004) Screening of Vibrio isolates to develop an experimental infection model in the Pacific oyster Crassostrea gigas. Diseases of Aquatic Organisms 59, 49-56.

[30] Reed, L.J. and Müench, H. (1938) A simple method of estimating fifty per cent endpoints. The American Journal of Hygiene 27, 493-497.

[31] Delaporte, M., Soudant, P., Moal, J., Lambert, C., Quere, C., Miner, P., Choquet, G., Paillard, C. and Samain, J. (2003) Effect of a mono-specific algal diet on immune functions in two bivalve species-Crassostrea gigas and Ruditapes philippinarum. Journal of Experimental Biology 206, 3053-3064.

[32] Hégaret, H., Wikfors, G.H. and Soudant, P. (2003) Flow cytometric analysis of haemocytes from eastern oysters, Crassostrea virginica, subjected to a sudden temperature elevation: II. Haemocyte functions: aggregation, viability, phagocytosis, and respiratory burst. Journal of Experimental Marine Biology and Ecology 293, 249-265.

[33] Bass, D.A., Parce, J.W., Dechatelet, L.R., Szejda, P., Seeds, M.C. and Thomas, M. (1983) Flow cytometric studies of oxidative product formation by neutrophils: a graded response to membrane stimulation. Journal of Immunology 130 , $1910-1917$.

[34] Hegaret, H., Wikfors, G.H. and Soudant, P. (2003) Flow cytometric analysis of haemocytes from eastern oysters, Crassostrea virginica, subjected to a sudden temperature elevation: I. Haemocyte types and morphology. Journal of Experimental Marine Biology and Ecology 293, 237-248.

[35] Curtin, J.F., Donovan, M. and Cotter, T.G. (2002) Regulation and measurement of oxidative stress in apoptosis. Journal of Immunological Methods 265, 49-72.

[36] Liu, P.-C., Chen, Y.-C., Huang, C.-Y. and Lee, K.-K. (2000) Virulence of Vibrio parahaemolyticus isolated from cultured small abalone, Haliotis diversicolor supertexta, with withering syndrome. Letters in Applied Microbiology 31, 433-437. 
[37] Huang, C.-Y., Liu, P.C. and Lee, K.-K. (2001) Withering syndrome of the small abalone, Haliotis diversicolor supertexta, is caused by Vibrio parahaemolyticus and associated with thermal induction. Zeitschrift für Naturforschung $56,898-901$.

[38] Nottage, A.S. and Birkbeck, T.H. (1990) Interactions between different strains of Vibrio alginolyticus and hemolymph fractions from adult Mytilus edulis. Journal of Invertebrate Pathology 56, 15-19.

[39] Lane, E. and Birkbeck, T.H. (1999) Toxicity of bacteria towards haemocytes of Mytilus edulis. Aquatic Living Resources 12, 343-350.

[40] Basu, I., Mitra, R., Saha, P.K., Ghosh, A.N., Bhattacharya, J., Chakrabarti, M.K., Takeda, Y. and Nair, G.B. (1999) Morphological and cytoskeletal changes caused by non-membrane damaging cytotoxin of Vibrio cholerae on Int 407 and HeLa cells. FEMS Microbiology Letters 179, 255-263.

[41] Borrego, J.J., Luque, A., Castro, D., Santamaria, J.A. and Martinez-Manzanares, E. (1996) Virulence factors of Vibrio P1, the causative agent of brown ring disease in the Manila clam, Ruditapes philippinarum. Aquatic Living Resources 9, 125-136.

[42] Bayne, C.J. (1990) Phagocytosis and non-self recognition in invertebrates. Phagocytosis appears to be an ancient line of defence. Bioscience 40, 723-731.

[43] Silva, C.P., Waterfield, N.R., Daborn, P.J., Dean, P., Chilver, T., Au, C.P.Y., Sharma, S., Potter, U., Reynolds, S.E. and Ffrench-Constant, R.H. (2002) Bacterial infection of a model insect : Photorhabdus luminescens and Manduca sexta. Cellular Microbiology 4, 329-339.

[44] Au, C., Dean, P., Reynolds, S.E. and Ffrench-Constant, R.H. (2004) Effect of the insect pathogenic bacterium Photorhabdus on insect phagocytes. Cellular Microbiology 6, 89-95.

[45] Lambert, C., Soudant, P., Jegaden, M., Delaporte, M., Labreuche, Y. and Paillard, C. (2004) Measurement of oyster (Crassostrea gigas) hemocyte oxydative burst by flow cytometry : application to evaluate defence capacity of oysters selected on their survival performance to summer mortality. The Sixth International Symposium on Fish Immunology; Turku (Finland), 25-29 May 2004.

[46] Torreilles, J., Guerin, M.C. and Roch, P. (1996) Reactive oxygen species and defense mechanisms in marine bivalves. C. R. Acad. Sci III. 319, 209-218.

[47] Klebanoff, S.J. (1982) Oxygen-dependent cytotoxic mechanisms of phagocytes. J.I. Gallin \& A.S. Fauci (Editors), Advances in Host Defence Mechanisms. 1. Raven Press, New York. 
[48] Densmore, C.L., Smith, S.A. and Holladay, S.D. (1998) In vitro effects of the extracellular protein of Renibacterium salmoninarum on phagocyte function in brook trout (Salvelinus fontinalis). Veterinary Immunology and Immunopathology 62, 349-357.

[49] Villamil, L., Figueras, A., Aranguren, R. and Novoa, B. (2003) Non-specific immune response of turbot, Scophthalmus maximus (L.), experimentally infected with a pathogenic Vibrio pelagius. Journal of Fish Diseases 26 , 321-329.

[50] Hofman, P., Le Negrate, G., Mograbi, B., Hofman, V., Brest, P., Alliana-Schmid, A., Flatau, G., Boquet, P. and Rossi, B. (2000) Escherichia coli cytototxic necrotizing factor-1 (CNF-1) increases the adherence to epithelia and the oxidative burst of human polymorphonuclear leukocytes but decreases bacteria phagocytosis. Journal of leukocyte biology $68,522-528$.

[51] Falzano, L., Rivabene, R., Santini, M., Fabbri, A. and Fiorentini, C. (2001) An Escherichia Coli cytotoxin increases superoxide anion generation via Rac in epithelial cells. Biochemical and Biophysical Research Communications 283.

[52] Brown, S., Howell, M., Vasil, M., Anderson, A. and Hassett, D. (1995) Cloning and characterization of the katB gene of Pseudomonas aeruginosa encoding a hydrogen peroxide-inducible catalase: purification of KatB, cellular localization, and demonstration that it is essential for optimal resistance to hydrogen peroxide. Journal of Bacteriology $177,6536-6544$.

\section{Figure captions}

Fig. 1 Flow cytometer FL1 histogram plot of oyster hemocytes (Events) incubated with fluorescent latex beads. The line labeled M1 indicates the position of the marker used to assess the proportion of hemocytes containing 3 beads or more.

Fig. 2 Flow cytometer density plot of C. gigas hemocytes allowing the distinction of sub-populations (agranulocytes, granulocytes and hyalinocytes) according to their relative size (FSC) and complexity (SSC) after gating all active cells showing DCF fluorescence.

Fig. 3 Phagocytic activity of hemocytes (percentage of hemocytes containing 3 beads or more) submitted to increasing concentrations of ECPs $\left(\mu \mathrm{g} \cdot \mathrm{mL}^{-1}\right)$. Letters indicate significant difference between treatments (mean $\pm \mathrm{S} . \mathrm{D}$.; $\mathrm{N}=4$; 
ANOVA P $<0.05)$.

Fig. 4 Percentage of adherent hemocytes submitted to increasing concentrations of ECPs $\left(\mu \mathrm{g} \cdot \mathrm{mL}^{-1}\right)$. Letters indicate significant difference between treatments (mean \pm S.D.; N=4; Kruskal-Wallis, $\mathrm{P}<0.05$ ).

Fig. 5 Mean ROS production level (DCF fluorescence in arbitrary unit A.U.) of hemocytes submitted to increasing concentrations of ECPs $\left(\mu \mathrm{g} \cdot \mathrm{mL}^{-1}\right)$ at 60 and 120-min. Asterisk $(*)$ indicates significant differences with FSSW control (mean \pm S.D.; N=4; ANOVA, P $<0.05$ ). (a) : granulocytes (b) : hyalinocytes

Fig. 6 Phagocytic activity of hemocytes (percentage of hemocytes containing three beads or more) submitted to low concentrations of ECPs (from 0.1 to $2-\mu \mathrm{g} \cdot \mathrm{mL}^{-1}$ ) . Letters indicate significant difference between treatments (mean \pm S.D., $\mathrm{N}=4$, ANOVA $\mathrm{P}<0.05$ )

Fig. 7 Percentage of adherent hemocytes submitted to low concentrations of ECPs (from 0.1 to $2-\mu \mathrm{g} \cdot \mathrm{mL}^{-1}$ ) Letters indicate significant difference between treatments (mean \pm S.D., $\mathrm{N}=4$, ANOVA $\mathrm{P}<0.05$ )

Fig. 8 Phagocytic activity of hemocytes (percentage of hemocytes containing three beads or more) after 1-h exposure to ECPs (2 and 32- $\mu \mathrm{g} \cdot \mathrm{mL}^{-1}$ ) or to $V$. aestuarianus $01 / 32$ live cells (50 bacteria/ hemocyte). Letters indicate significant difference between treatments (mean \pm S.D.; $\mathrm{N}=4$; Kruskal-Wallis, $\mathrm{P}<0.05$ ).

Fig. 9 Percentage of adherent hemocytes after 3 -h exposure to ECPs ( 2 and $32-\mu \mathrm{g} . \mathrm{mL}^{-1}$ ) or to $V$. aestuarianus $01 / 32$ live cells (50 bacteria/ hemocyte). Letters indicate statistical difference between treatments (mean \pm S.D.; N=4; ANOVA, $\mathrm{P}<0.05$ ).

Fig. 10 Mean ROS production level (DCF fluorescence in arbitrary unit) of hemocytes stimulated by ECPs (2 and 32$\mu \mathrm{g} . \mathrm{mL}^{-1}$ ) or $V$. aestuarianus $01 / 32$ live cells (50 bacteria/ hemocyte). Letters indicate statistical difference with FSSW condition (control) (mean \pm S.D.; N=4; ANOVA, $\mathrm{P}<0.05)$. (a) : granulocytes (b) : hyalinocytes 


\section{Tables}

Table 1: Virulence tests of ECPs produced by $V$. aestuarianus $01 / 32$ strain injected in a volume of 0.2 -mL into $C$. gigas oysters weighing $5 \pm 1 \mathrm{~g}$

\begin{tabular}{ccc}
\hline $\begin{array}{c}\text { Dose per oyster } \\
\left(\mu \mathrm{g}^{-1} \text { body weight }\right)^{10}\end{array}$ & No of dead oysters ${ }^{\text {a }}$ & Relative virulence $^{\mathbf{b}}$ \\
\hline 10 & 20 & $100 \%$ \\
5 & 14 & $78.6 \%$ \\
2.5 & 8 & $30.8 \%$ \\
1.25 & 0 & $0 \%$ \\
\hline
\end{tabular}

$\mathrm{LD}_{50} \quad 3.3 \mu \mathrm{g} . \mathrm{g}^{-1}$ body weight

a : expressed as the number of oysters dying over the total number of oysters in the treatment. Overall results of duplicate trial are presented.

b : expressed by dividing the cumulative number of dead oysters with the cumulative total number of oysters injected. 


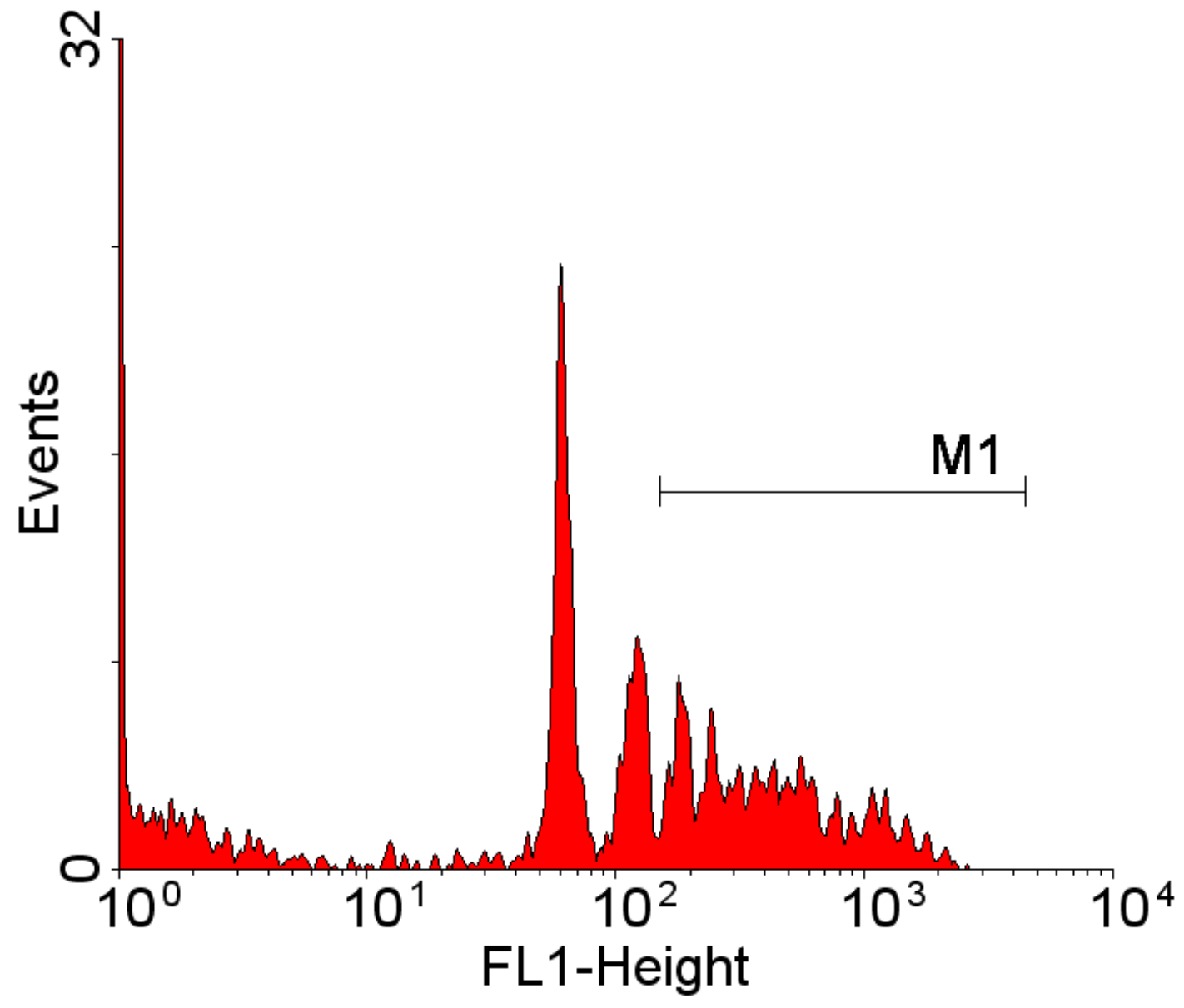

Fig. 1 


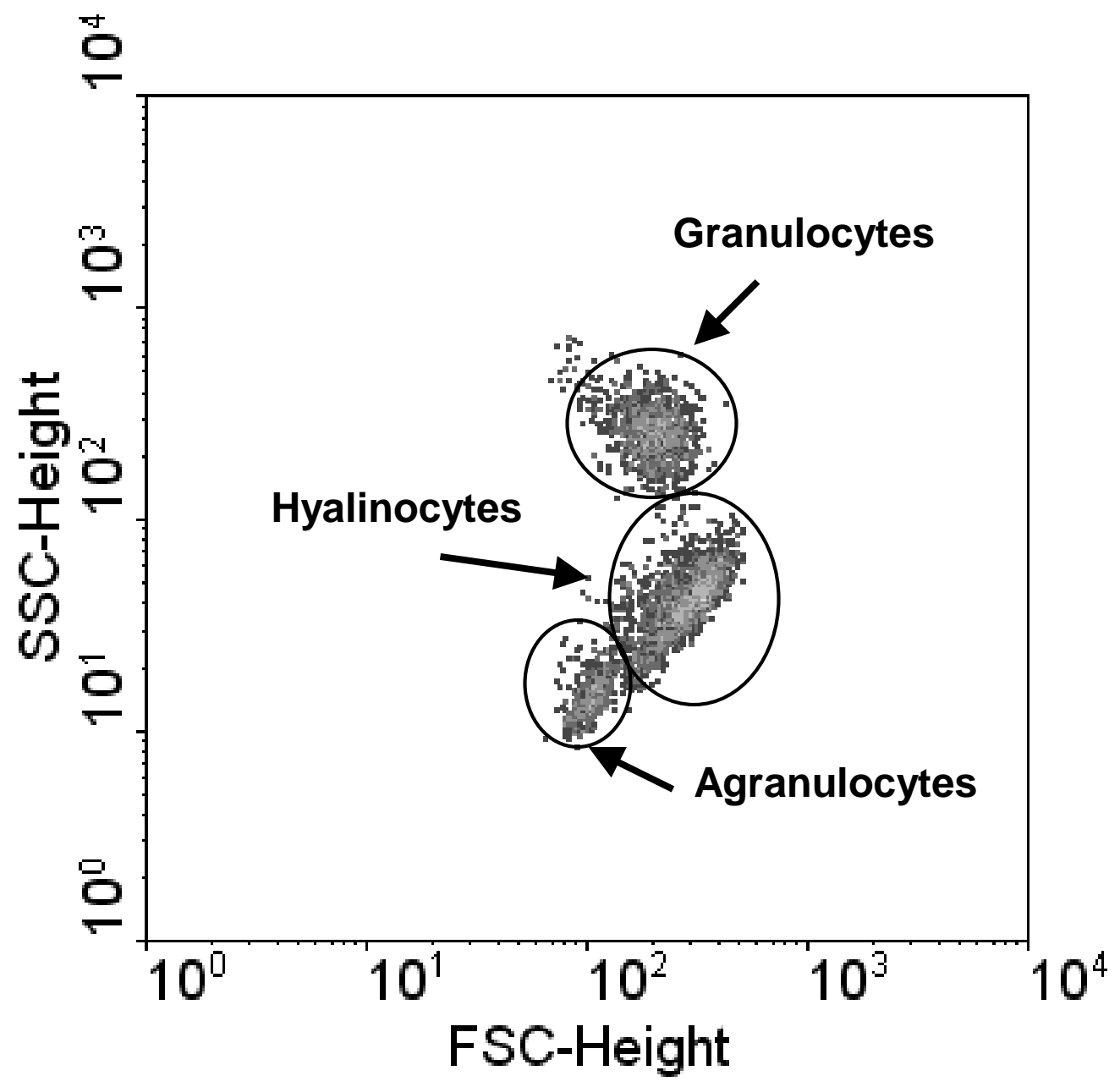

Fig. 2 


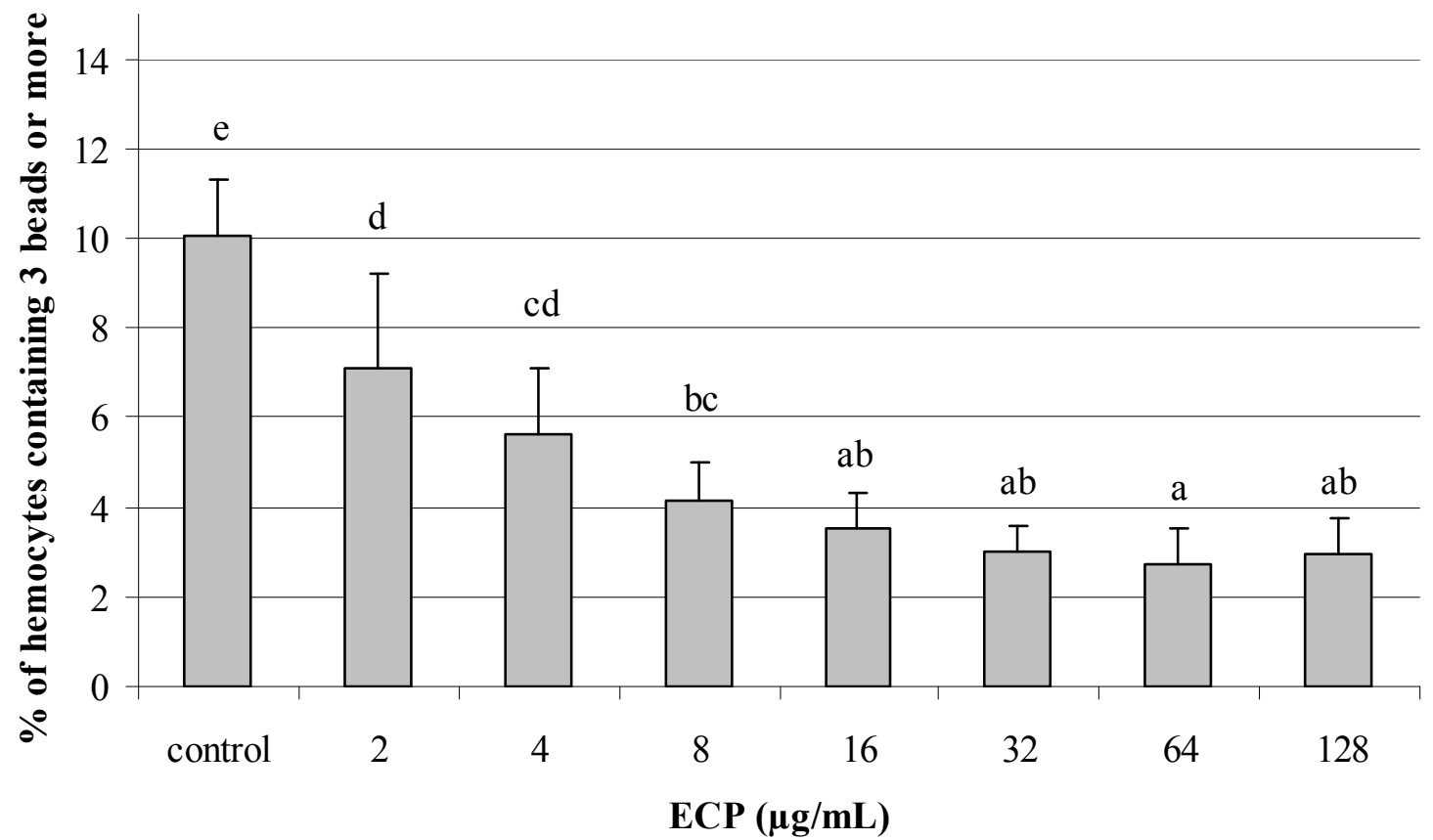

Fig. 3 


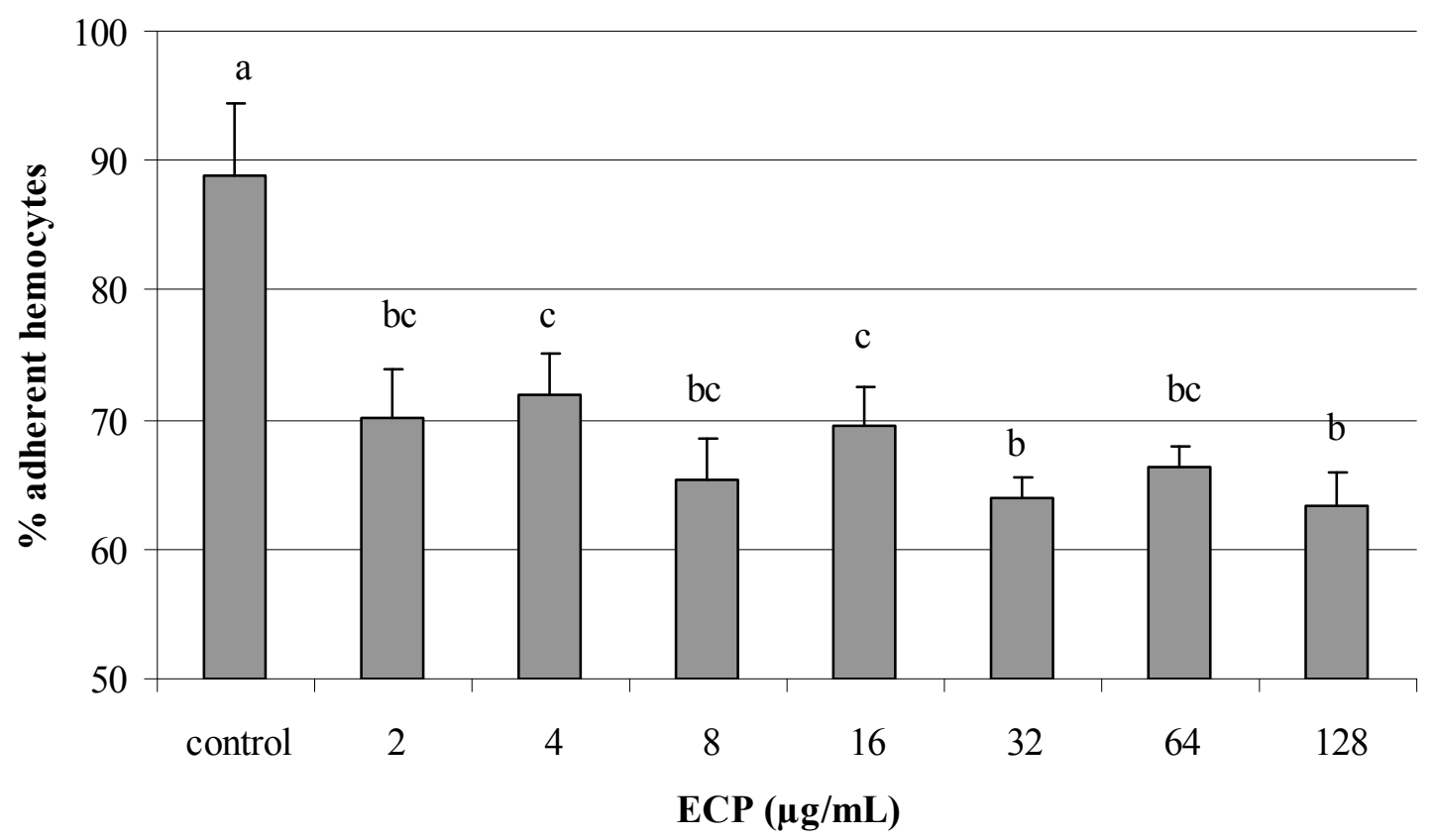

Fig. 4 

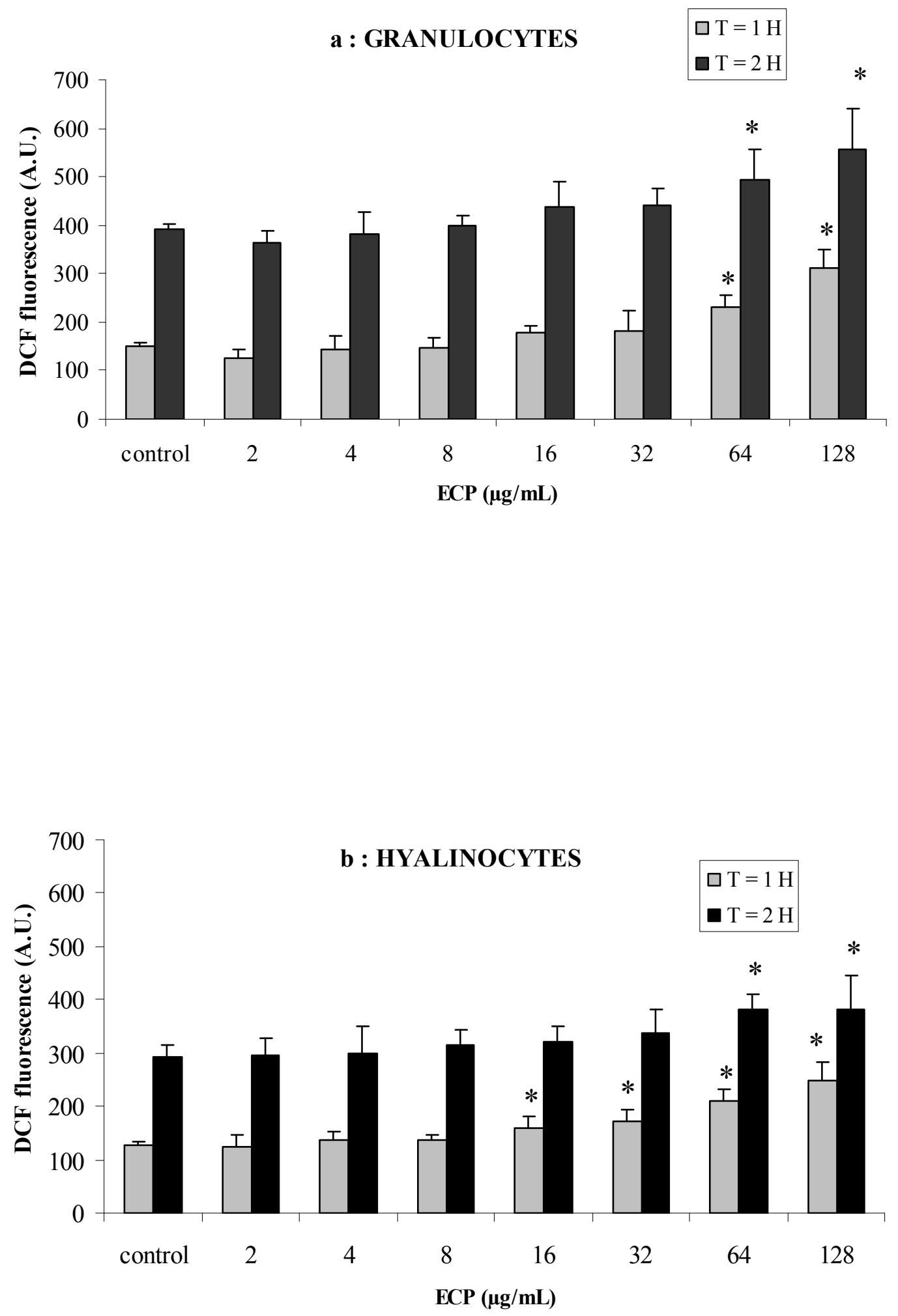

Fig. 5 


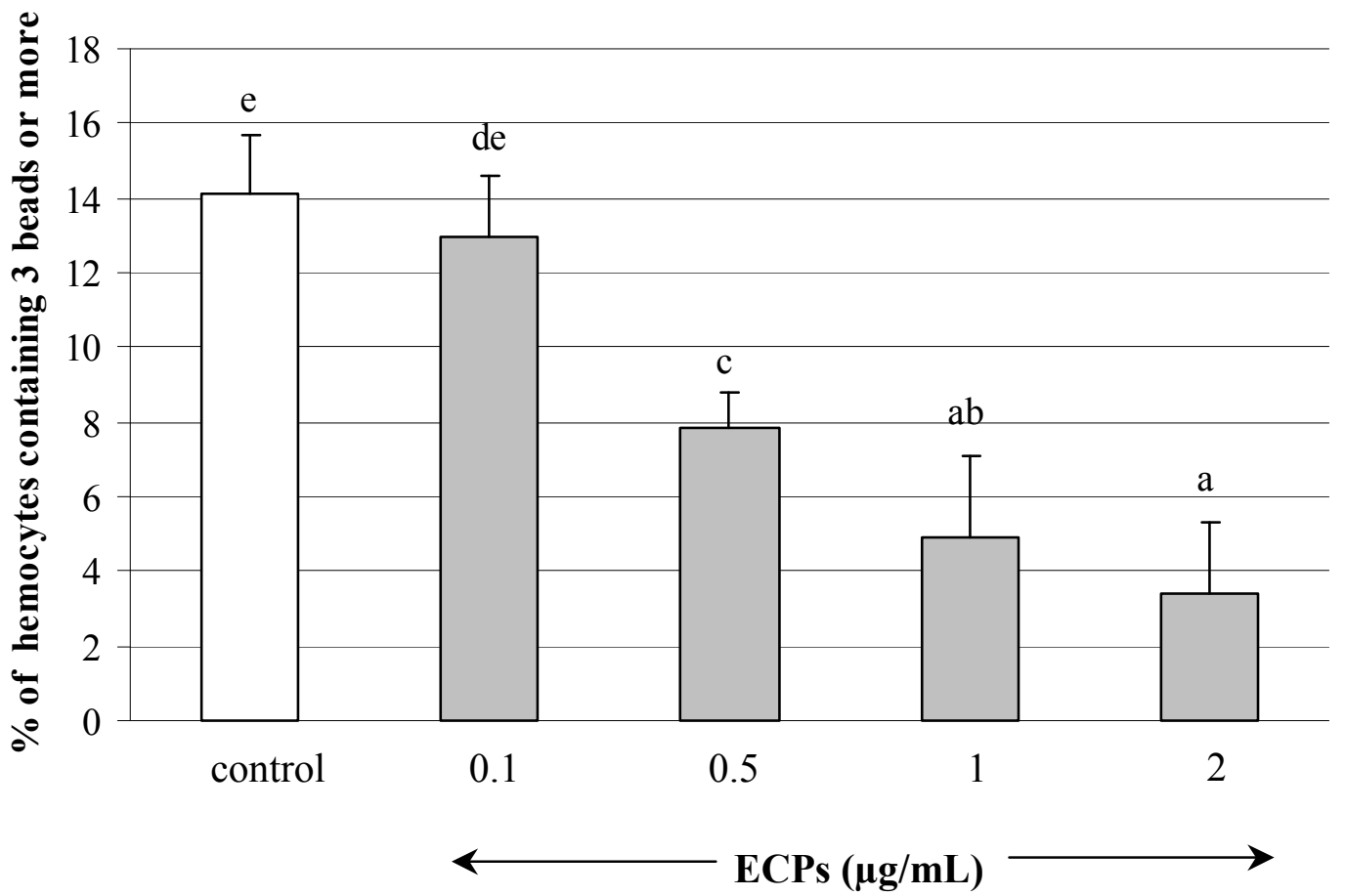

Fig. 6 


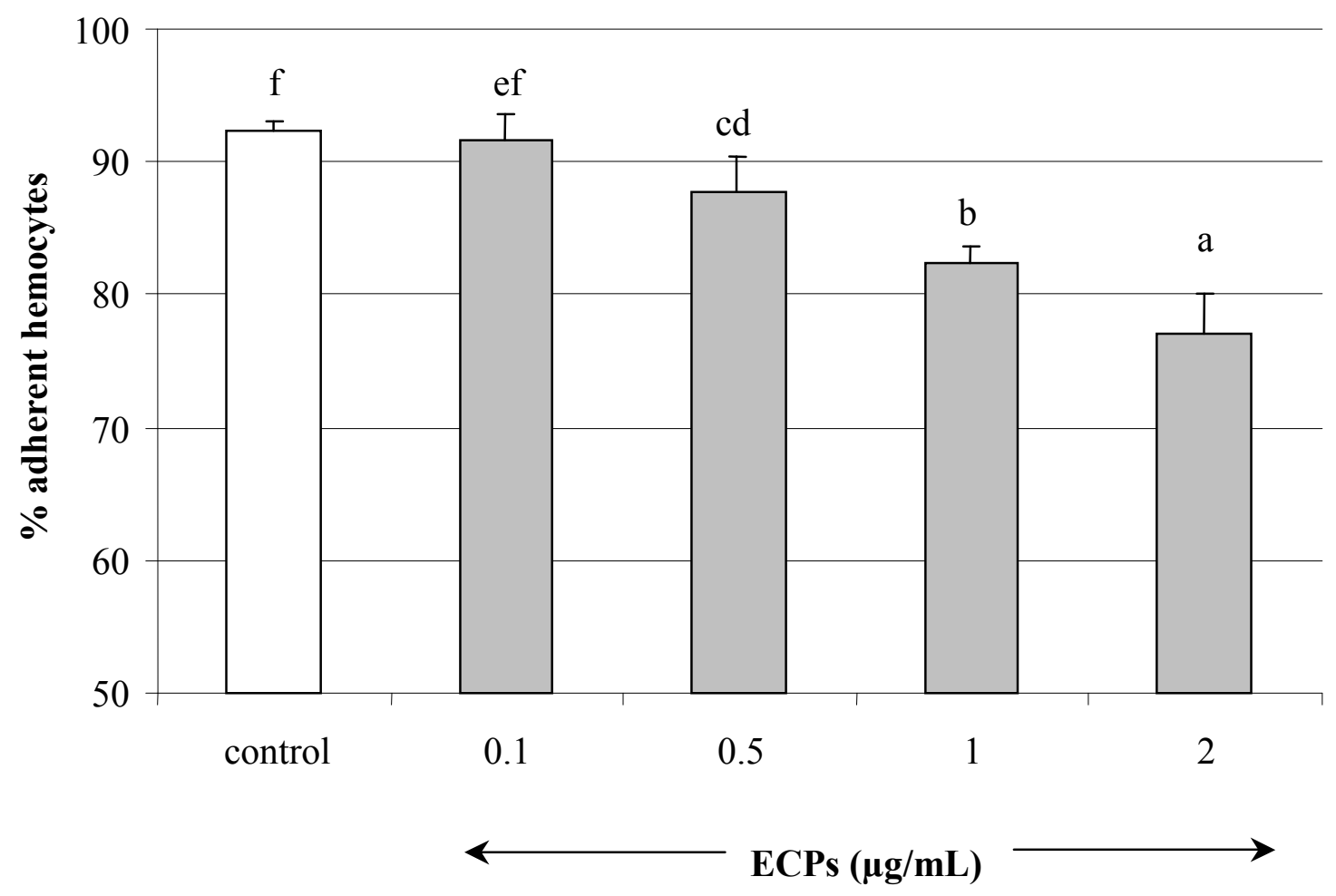

Fig. 7 


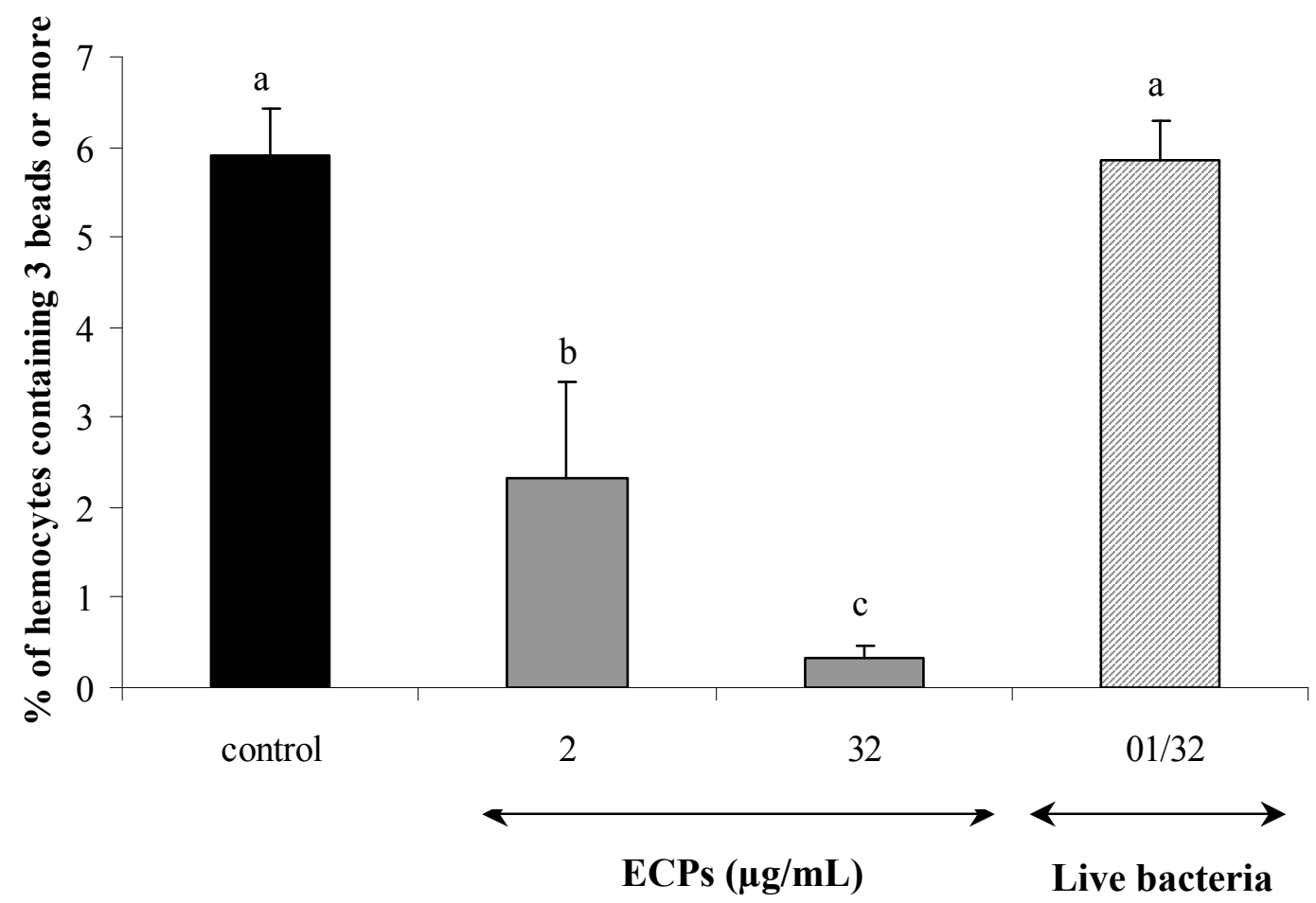

Fig. 8 


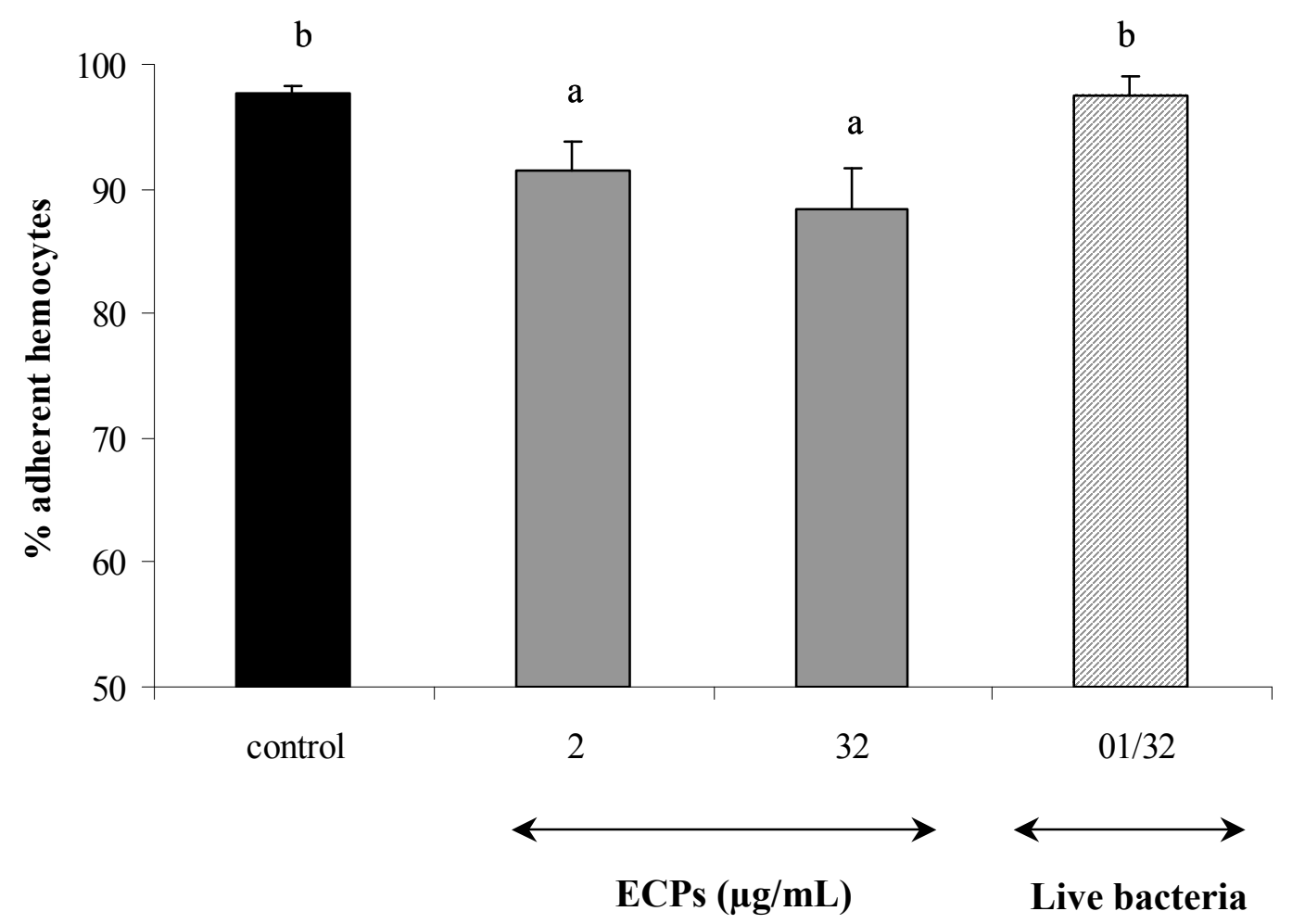

Fig. 9 


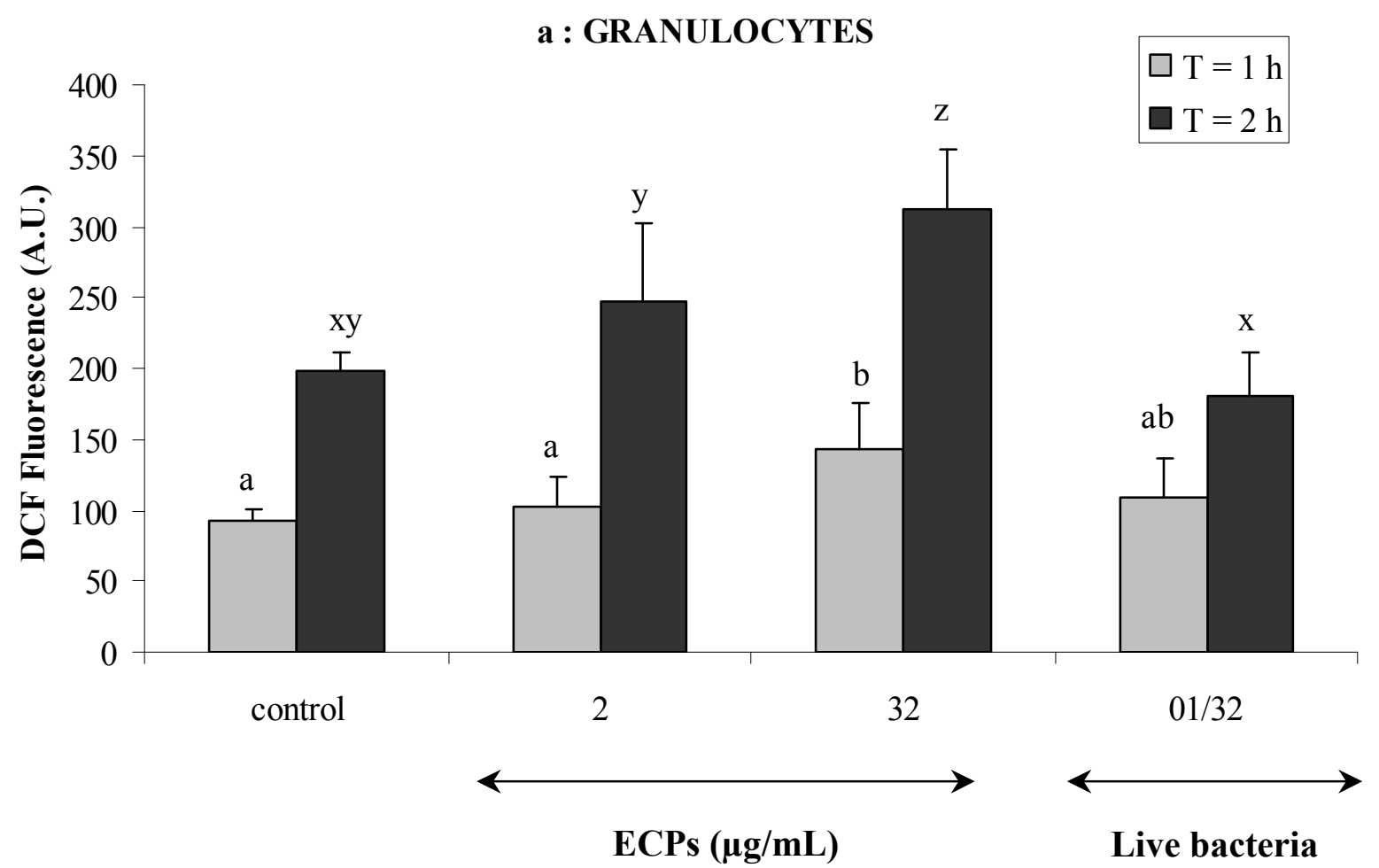

b : HYALINOCYTES

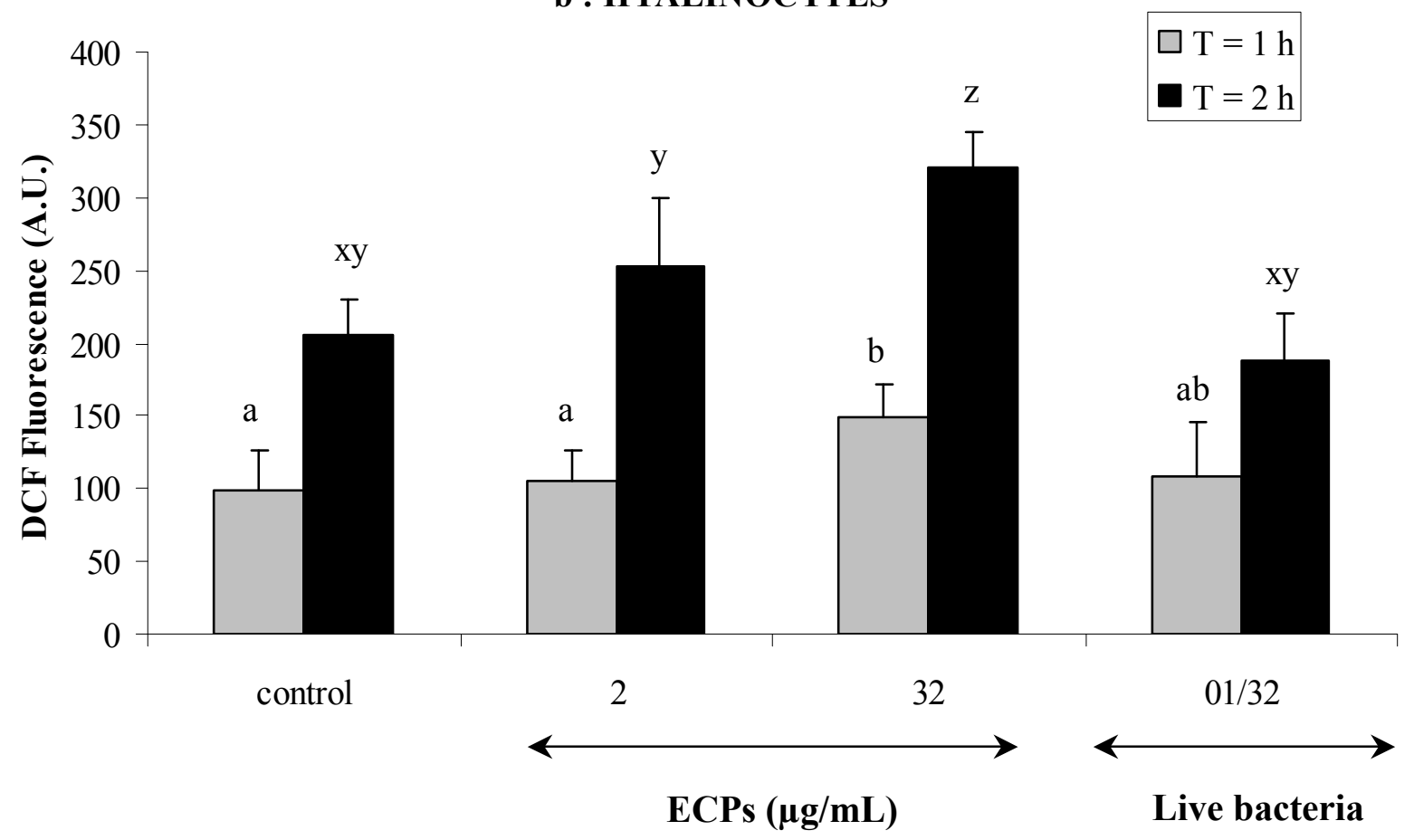

Fig. 10 